\title{
The Authority of Police Discretion in Actualizing the Repressively Fair Law Enforcement in Indonesia
}

\author{
I Gusti Kade Budhi Harryarsana \\ A Doctoral Student of Legal Studies Faculty of Law Udayana University
}

\begin{abstract}
The aim of this study is to investigate and analyze the base and the regulation of the authority of the police discretion in doing repressive legal duties that are fair in the police legislation in Indonesia. The problem that exists is the current police discretion, which has the potential to be extremely close to the abuse of authority by the police members in doing their duties. Therefore, this study focuses on the relationship between the regulation of police discretion and Police Professional Ethics Code, which is a moral base for the implementation of police duties. In addition to the professional ethics code that is used as the base for the implementation of police duties, the police members' action must not differ from those specified in law. In this case, Law Number of 2002 concerns the National Police of Indonesia Republic, in which it is determined that the police action must also take into account the Human Rights. This is an interesting phenomenon to study by using normative legal research methods, namely tracking legal materials related to the problem. The results of this study shows that the base and the regulation of Indonesia police discretion have been based on laws, regulations, and the police professional ethics code. However, there are no clear and explicit limits to actions that must be taken and this concerns how these actions are responsible for fair law enforcement.
\end{abstract}

Keywords: Authority, Discretion, Police, Repressive, Fair

DOI: $10.7176 / J L P G / 82-16$

\section{Introduction}

In the constitutional state, the government must have the authority as the base of orderly law and become the basic of the legality to act.(Fahmal, 2008:4) Without the authority, the government is not able to make a right juridical decision. (Thalib, 2006: 219) In other words, the instrument of the authority becomes extremely important in the implementation of government duty, including what the law enforcer institution in Indonesia does.

The law enforcement in Indonesia essentially follows the development of the society that develops rapidly along with the spread of law supremacy phenomena, human rights, globalization, democratization, decentralization, transparency, and accountability, which has given rise the new paradigms in law enforcement. Law enforcement in this case is a series of processes to describe the abstractions of values, ideas, and ideals to be the goal of the law. The purpose of law as a goal in law enforcement contains values of truth and justice. The law enforcement is an effort to realize harmony between das sollen (values in rules) with das sein (reality in society). A new paradigm in enforcement considers that law enforcement is not just a mere law enforcement monopoly such as the police, lawyers, prosecutors, and judges, but also the community is expected to actively participate in guarding the law enforcement process.

In the relation to National Police of Indonesian Republic, this institution has a strategic position in law enforcement. The police are expected to be able to carry out government functions in relation to maintaining and keeping the order and the secure of the society through the implementation of legal sanctions that reduce and / or burden the freedom and enjoyment of the community for their violations of society's order as stated in provisions of criminal law. On the other hand, the police are also one of the institutions that participate in carrying out government duties in serving the public interest. Therefore, the police in the law enforcement process acts as the gate guard of the law enforcement process.

The presence of the police in resolving various community issues is certainly very necessary in order to protect and promote the welfare of the Indonesian people. The broad scope of police duties and in order to realize the Indonesian state as a welfare state mandated by the fourth paragraph of the Preamble of the 1945 Constitution, the police apparatus is required to always be able to act quickly in the public interest, in terms of:

a. protect the entire Indonesian nation and all of Indonesia's bloodshed;

b. advance public welfare;

c. educate the life of the nation, and

d. carry out world order based on eternal peace and social justice.

Article 4 of Law No.2 of 2002 also emphasizes, "The Republic of Indonesia National Police aims to realize internal security which includes the maintenance of public security and order, orderly and upholding the law, the implementation of protection, and service to the community, as well as maintaining public peace high human rights". The implementation of police functions is the implementation of the profession, meaning that in carrying out the duties of a member of the police, they use their professional abilities, especially expertise in the technical 
field of the police. In carrying out their duties as law enforcers, the police always respect the law and human rights. Therefore, in carrying out his profession, every member of the police is subject to the professional code of ethics as a moral foundation in acting.

The police professional code of ethics are norms or rules which constitute a unified ethical or philosophical foundation with behavioral regulations and sayings about things that are required, prohibited, or inappropriate for Indonesian Police members to do. This is stated in the provisions of Article 1 point 2 of the Regulation of the Head of the Indonesian National Police Number 7 of 2006 concerning the Professional Code of Ethics of the Republic of Indonesia National Police. The application of this professional code of ethics in the regulation of police discretion requires a search of various legal materials relating to discretion starting from orders, implementation up to the responsibility for such discretionary actions.

The problematic law related to the authority of discretion will be further investigated with appropriate legal material through normative research methods. In normative legal research, it is used namely primary legal material, secondary legal material and tertiary legal material (Fajar ND \& Achmad, 2013: 42). In this case, the related ones start from the main reference, namely legislation to articles that are related to the discussion.

\section{Literature Review}

\subsection{The Discretion in Repressive Law Enforcement}

Discretion is a power or authority that is carried out based on law on consideration and belief and emphasizes more moral considerations than legal considerations.(M. Faal, 1991:23) Discretionary power possessed by the police shows that the police have great power because the police can make decisions where their decisions can be outside the provisions of the law, but are justified or allowed by law. According to Samuel Walker that one thing can explain the power of the police or other institutions in carrying out their duties, namely the existence of discretion or authority given by law to act in special situations in accordance with the assessment and conscience of the agency or the officers themselves. .(Susanto, 2004: 98)

The implementation of discretion by the police seems to be against the law, but it is a solution that is indeed given by the law to the police in order to provide efficiency and effectiveness for the greater public interest, then discretion should not be eliminated. Discretion is an integral part of the role of the institution or organization. However, discretion can be limited and controlled, for example by the tightening of written orders and programmed decisions that are least able to compile and demand discretionary actions. The problem is that spontaneous decisions often appear and open the door wide for discretion taking.

Discretion, although it can be said is freedom in making decisions, but this is not an arbitrary thing that can be done by the police. Discretion is equated with arbitrariness to act or do whatever the police want. Police Discretion is basically the authority of the Police which is based on the principle of the General Obligation of the Police (Plichtmatigheids beginsel), which is the principle that gives police officials the authority to act or not act in their own judgment, in the context of the general obligation to maintain, maintain order and guarantee public security.

The Police Discretion can also be interpreted as the authority of members of the Police to choose to act or not act in carrying out their duties. Discretion allows a member of the Police to choose between various roles, namely protecting the community, protecting the community, serving the community, enforcing the law and / or maintaining order. Then determine tactics, for example in maintaining traffic order, tactics that are carried out are by patrolling or guarding a place, and based on the purpose of enforcing the law can give a ticket to the offender or by advising him. A member of the Police can apply discretion in the various events he faces daily but various literatures on discretion are more focused on selective action (Selective Enforcement) that is related to factors that influence whether a lawbreaker will be dealt with or not. Discretion is generally attributed to two concepts, namely selective and directed patrol.

Selective action is a form of administrative discretion where policy makers or leaders determine priorities for various units of subordinate units. For example, there is a policy to crack down on drug traffickers and let their users, allow prostitution in certain places and take action against street prostitutes. Directional patrol is an example of a supervisor's discretion where the supervisor instructs its members to closely monitor a particular area or a particular activity. For example, due to reports from the public, a Police Inspector ordered patrol officers to disperse a crowd of young people who were disturbing public order which was usually left unchecked. Another example is the order to ticket vehicles that are parked in a certain place due to disturbing the smooth flow of traffic. The use of the discretionary authority by members of the Police has only recently been recognized as a reasonable authority of the members of the Police.

Previously the leaders of the Police and the community assumed that the Police must take action against any violator of the legal provisions and allow or not carry out these provisions as violations of law by members of the Police. A small number of members of the DPR, Prosecutors and Judges still hold this opinion. The leaders in the Police are still hesitant to admit that members of the Police always use discretion in enforcing the law and that they secretly establish policies not to carry out full repression of minor crimes or violations of regional regulations. 
Therefore, in the Police Law, there are several requirements that must be met if a member of the police will conduct discretion, namely:

1. Actions must be absolutely necessary (noodzakelijk notwendig) or the principle of necessity.

2. The actions taken must be true for the interests of the police task (zakelijk, sachlich).

3. The most appropriate action to achieve the goal is the loss of a disturbance or not something that is feared. According to H.R. Abdussalam,(2009:51) actions taken by the police are always based on considerations based on moral principles and institutional principles, as follows:

a. The moral principle, that moral conception will give concessions to someone, even if he has committed a crime.

b. The institutional principle, that the institutional goals of the police will be more secure if the law is not carried out rigidly to cause resentment among ordinary citizens who are obedient to the law.

2.2 Discretionary Arrangements in Repressive Law Enforcement

The regulation of the authority of discretion of the Police is stipulated in the provisions of Article 18 of the Police Law, which determines:

(1) For the public interest of the National Police of the Republic of Indonesia in carrying out their duties and authorities, they can act in their own judgment.

(2) The implementation of the provisions referred to in paragraph (1) can only be carried out in very necessary circumstances by taking into account the laws and regulations, as well as the Professional Code of Ethics of the Republic of Indonesia National Police.

Meanwhile, the explanation of Article 18 paragraph (1) of the Police Law determines as follows:

What is meant by "acting according to his own judgment" is an action that can be carried out by members of the Republic of Indonesia National Police who in their actions must consider the benefits and risks of their actions and are truly in the public interest.

Whereas paragraph (2) of the provisions of Article 18 stipulates quite clearly, so that what is meant by "very necessary conditions" has not received further explanation. Likewise related to the explanation of paragraph (1), it is found that there is still a runaway because the meaning of self-assessment, benefits and risks, and then the meaning of public interest still requires a more concrete explanation to avoid multiple interpretations based on the interests of the interpreter.

The consequences of the obscurity of the norm in the application of the Discretionary authority by the Police, in practice there have been various cases of violations in law enforcement. The Head of Police Public Relations Division at the National Police Headquarters on Monday, October 10, 2016 stated that there were unscrupulous officers of the police who were suspected of extorting death row inmates for drug cases. Kadiv Humas also did not deny the number of individuals who took advantage of positions in the Police for personal gain. On the other hand, Sindonews.com media reported, "Throughout 2017 a number of police officers experienced a Respectful Dismissal aka being fired. The majority of Respectful Dismissals are due to police personnel making irregularities and abuse of authority ". This is in line with the opinion of the Head of the Defense Division for Political Civil Rights from the Commission for Missing Persons and Victims of Violence on Wednesday, September 21, 2016, who found 38 cases leading to abuse of authority by police and other law enforcement officers in handling cases narcotics, related to the provision of whistleblower status and justice collaborator (JC), rehabilitation of narcotics abusers, and covert purchase and control delivery operations.

In a legal state, all actions of equipment of the state or ruler are based on the law to provide protection to the state apparatus and the public. The existence of the law in the administration of government since ancient times was realized by Lord Acton as quoted by Sjachran Basah (1995: 1-2) who said that:

Every little power tends to be misused. Therefore, with the freedom of action of the state administration that enters all sectors of people's lives including the field of taxation, it can sometimes cause harm to the community itself. It is natural then that there is a desire that there is a guarantee that the state will not lead to a dictator without limits, which is contrary to the characteristics of the rule of law. So that protection of citizens is given when the attitude of the state administration causes harm to it. Moreover, the task of public services carried out by the state administration must be based on State Administrative Law so that in terms of carrying out these tasks actively. This means that in carrying out government, the state administration carries out an act of stipulation (beschikkingshandeling) which produces provisions (beschikking).

\section{Result and Discussion}

3.1 Regulation of the Discretionary Authority of the Police Agency in Repressive Law Enforcement in the Police Law

The police are law enforcers who directly deal with the community. The police are essentially living laws, because in the hands of the police the law can be realized especially in the field of criminal law. One of the objectives of the law is to create order in society, which among other things is done against crime. The police will determine 
concretely the enforcement of order, namely who must be subdued and who must be protected. Through the Police, abstract laws are transformed into reality. It can be mentioned that, Police work is law enforcement inoptima forma, Police are living laws. Through the Police, promises and legal objectives to secure and protect the community come true.

Giving discretion to the police is essentially contrary to the principle of acting according to the law. Discretion removes certainty about something that will happen, while one of the functions of law is guaranteeing certainty. Because of that discretion is the completeness of the regulatory system by the law itself. Discretion in handling various problems or violations of the law there are no clear rules or restrictions so that they often deviate from the provisions or principles of discretion. The problems in the implementation of discretion carried out by the police are: First, individual nature by police officers on the ground is the basis of what is known or understood by officers in the field that is considered correct.

This can also be caused by poor control systems (pseudo control). Another thing that affects is from the people who are sometimes reluctant to settle their cases with legal channels. In addition to being suitable for discretion, it is also important for the implementation of police duties for several reasons:

a) The law is written in a language that is too general to be used as an implementation guide to details for officers in the field.

b) Law is a tool for realizing justice and maintaining order and legal action is not the only way to achieve this.

c) Consideration of resources and capabilities of police officers.

According to James Q Wilson, there are four types of situations of possible discretionary actions, namely:

1) Police-invoked law enforcement, the officer is quite broad in reason to carry out discretionary actions, but the possibility is modified by the policies of the leadership;

2) Citizen-invoked law enforcement, discretion is very unlikely to be implemented, because the initiator is a community;

3) Police-invoked maintenance orders, intermediate discretion and leadership control, whether the leader will order easy or more vigorous take it; and

4) Citizen invoked maintenance orders, the implementation of discretion needs to be done even though the supervisor does generally not approve it.

The legal basis for Police Discretion includes Law Number 2 Year 2002 Article 18 paragraph (1) that

"For the public interest of the National Police of the Republic of Indonesia in carrying out their duties and authorities, they can act according to their own judgment". If discretion is applied incorrectly, there will be deviation, according to the Theory of Klitgard (1998), as quoted by Meliala to explain discretionary deviations as police corruption is as follows:

$\mathrm{C}=\mathrm{P}+\mathrm{D}-\mathrm{A}$

Description: $\mathrm{C}=$ Corruption, $\mathrm{P}=$ Power, $\mathrm{D}=$ Discretion, $\mathrm{A}=$ Accountability.

According to Jerimi Pope, "Corruption involves part of officials' behavior in the public sector; whether the politician or civil servants, in their improper and unlawfully enriched cells or those close to them by the misuse of the public power entrusted them" (Saputro Paul: 2000).

Discretion in handling various problems or violations of the law there are no clear rules or restrictions so that they often deviate from the provisions or principles of discretion. The problems in the implementation of discretion carried out by the police are: First, individual nature by police officers on the ground is the basis of what is known or understood by officers in the field that is considered correct.

3.2 Regulation of the Discretionary Authority of the Police Institution in Repressive Law Enforcement in Laws Regarding Police Duty

According to Agus Adrianto in Ronnie Bonnie et al. (2016: 75), the Police of Indonesia Republic in doing police duties that include police activities and police operation are given discretionary power. The authority of discretion is a legal authority in which the police have the right to continue or not to continue with a case. Based on this authority, the police can differentiate a case so that the criminal does not need to face formal settlement of the criminal court. Discretion is not an authority but is another act of the police and must be legally and normally lawful in the community.(Rahardjo,2009:11)

The application of the Police Discretion, which cannot be prosecuted before the law, is regulated in Article 18 of Law No. 2 of 2002 and Article 7 of the Criminal Procedure Code, but of course, this authority can be carried out with certain considerations as boundaries. Therefore, the authority of discretion is now limited. The act of discretion by the police is limited by:

a. Principle of necessity, that action must be really needed.

b. Actions taken are truly in the interests of police duties. The principle of purpose, that the most appropriate action to eliminate a disturbance or not the occurrence of a concern about the consequences of greater.

c. The principle of balance, that in taking action must be taken into account the balance between the nature of the action or the target used with the size of the interference or the lightness of an object that must be acted upon. 
The policy steps taken by the police are usually understood by components of function within the criminal justice system, especially by prosecutors. The policy steps taken by the police according to M. Faal (1991: 65) are usually with the following considerations:

1) The use of local customary law is considered more effective than the applicable positive law.

2) Local law can be felt by parties between perpetrators, victims and the community.

3) The wisdom pursued is more beneficial than merely using the existing positive law.

4) By their own will.

5) Do not conflict with the public interest (M. Faal, 1991: 74)

Police discretion has not been formulated and elaborated in detail about the forms and types of actions included in the discretion, which are only in the form of limits or measures that are used as guidelines in making decisions to implement police discretion, limits in applying discretion explained in Article 16 paragraph 2 of the Act -Number No. 2 of 2002 states that the actions of investigators for the purpose of investigation with 5 (five) requirements are as follows:

a) does not conflict with a rule of law;

b) in line with legal obligations that require office action;

c) the action must be appropriate and reasonable and included in the office environment;

d) based on reasonable considerations based on force;

e) respect for human rights.

Power that cannot be avoided is an excess power, power that is generally considered to not be able to be resisted, an Overmatch, which is divided into 3 (three) types:

1. Absolute. In the case, that person cannot do anything else. He experienced something he could not avoid at all. He could not possibly choose another path, for example someone held by someone else who was stronger, thrown into a window, so that the glass broke and resulted in the crime of other people's goods.

2. Relative. Here the power or force that forces the person is absolute, not full. The person who was forced still had the opportunity to choose which one to do, for example A was held by B with a gun told to burn the house. If A does not quickly burn the house, the gun pointed at him will be fired.

3. Emergency. Power where a person is in an emergency, the person is forced to choose which criminal event he will commit. In a relative power, that person does not choose which crime he will do.

\subsection{The Impact of Regulatory Authority for the Discretion of the Police Agency on Repressive Law Enforcement} Tasks

The police as the leading institution in law enforcement efforts has the authority, among others, a series of investigations, searches, arrests, examinations and delegate cases to the prosecutor's office to be tried in court. With a series of sequences of activities, it appears that the police are law enforcement institutions.

One of the tasks assigned to the police is handling traffic problems both those, which are preventive and repressive. The police are required to maintain traffic order besides also having to enforce traffic criminal law.

The birth of the Law of the Republic of Indonesia Number 22 Year 2009 concerning Road Traffic and Transportation (hereinafter referred to as UULLAJ) in lieu of Law Number 14 of 1992 concerning Road Traffic and Transport provides confirmation to the police as state institutions that have the most extensive authority compared to other institutions in terms of enforcement of traffic criminal law and order on the highway.

The increasing number of residents in Lima Puluh Kota Regency affects the number of vehicles which also continues to increase from year to year. This is of course very directly proportional to the increase in traffic violations that occur, the Traffic Unit of the Payakumbuh Sector Police continues to strive to continue to improve performance in security and traffic services for the public. However, law enforcement carried out by the police alone is not enough, because it cannot be denied the comparison of the number of police officers on duty and the number of vehicles is very much different.

Accidents that occur are quite varied, from accidents of two-wheeled vehicles to four or more wheels. Traffic accidents that occurred in 2015 up to December were 132 cases with 25 people died, seriously injured 119 people and lightly injured 96 people. Of the total accidents, 10 cases were transferred to the prosecutor's office (P21), 26 cases were stopped by the investigation process SP3), as many as 88 cases were resolved using police discretion which was realized in an alternative dispute resolution (ADR), 8 cases were hit accidents run.

Given the vast scope of police duties, which are not only limited to law enforcement, but also include tasks in order to maintain public security, the police officers often face problems involving human rights (peace and tranquility of privacy) and state law that is not uncommon contrary to one another. Circumstances like this require the implementation of a policy acting on the personal consideration of the police officer concerned, known as discretion. The discretion needs to be applied on a basic basis, as follows:

1. There are no laws and regulations that can govern all human behavior 
2. There are no laws and regulations whose contents are clearly clear to the people who are regulated (for example in terms of language, and also their formation is not possible to cover all problems faced by community members)

3. What is regulated is humans who have differences, such as mentality, educational background, motivation to behave in certain ways, their potential to deviate, and so on.

4. It is very difficult to harmonize the need to establish legislation with facilities that support it.

Discretion for the police is a very important right to face very broad tasks, Barker argues that police discretion will never be eliminated and should not be eliminated.

3.4 The Impact of Regulations on the Discretion of the Police Institution's Authority on Repressive Law Enforcement Tasks that Are Equitable for the Community

In Article 2 of Law Number 2 of 2002 concerning State Police in the field of public security and order, the enforcement of Law No.2 of 2002 also affirms that the Republic of Indonesia National Police aims to realize internal security which includes maintaining public security and order, orderly and upright law, the implementation of protection, protection and service to the community, as well as the establishment of public tranquility by upholding human rights.

Against anarchist protesters, violence can be justified as long as within reasonable limits, but still must be done selectively and in a controlled manner. The crackdown from the police must remain based on applicable legal rules and uphold human rights. It is in the position that the police are required to use the discretionary authority inherent in police duties.

Discretion is the authority of the police to make decisions or choose various actions in resolving problems of violation of law or criminal cases handled. It is very important that this discretion can be done correctly by considering all aspects or things above with good ethics. Therefore, with this discretion, the actions taken by the Police must be in accordance with the rule of law.

The act of discretion that was decided by the police in the field directly at that time and without asking for instructions or decisions from their superiors was individual discretion, for example to avoid the accumulation of traffic flow on a road, police officers signaled to continue to the vehicle driver even though at that time the traffic regulator lights were red and so on.

Incidentally, community policing in Singapore has been institutionalized as a formal discourse by the Singapore Police (SPF) in 1980 (Quah and Quah 1987), and has been carried out as part of nation-building efforts since then. Community policing then functions well as a platform for restructuring internal organizations by the SPF and to continue to follow changes in the broader socioeconomic context. Unfortunately, many scholars have surprisingly polished the story of community policing in Singapore. This is despite the fact that the police community underwent significant changes in the direction of the organization in the 1990s (Singh 2000), which influenced the lives of many Singaporeans and frontline police officers in Indonesia in countless ways.

\section{Conclusion}

The base of the regulation regarding Indonesia police discretion is in agreement with laws and regulations, in this case Law Number 2 of 2002 concerning the National Police of Indonesia Republic and the professional police ethics code. However, indeed, in terms of implementation of police discretion, it has not been formulated and described in detail about the forms and types of actions included in the discretion. The regulation is only in the form of restrictions or measurements that are used as guidelines in making decisions to implement the police discretion.

In repressive law enforcement by the Police, there are still various problems. Besides being due to the human resource factor itself, of course the problem related to the clarity of legal products that regulate the implementation of the duties of the Police in carrying out repressive law enforcement duties cannot be ignored.

The police in carrying out its duties must use the Police Professional Ethics as a very fundamental and important basis and influence on the good or bad implementation of the Police Discretion. This ethics is the basis for forming a self-assessment for each member of the police in carrying out their duties.

Police Discretion is limited by:

1. The need, namely that the action must be necessary and must be taken in the interest of the police's duty.

2. The purpose, namely that the most appropriate action to eliminate a disturbance or not the occurrence of a concern about the consequences of greater.

\section{References}

A. Meliala. (1993). Menyingkap Kejahatan Krah Putih, Jakarta: Pustaka Sinar.

Abdussalam, H.R. (2009). Hukum Kepolisian Sebagai Hukum Positif dalam Dispilin Hukum. Jakarta: Restu Agung 
Basah, Sjahran. (1995). Pencabutan Izin Salah Satu Sanksi Hukum Administrasi, Makalah pada Penataran Hukum Administrasi dan Lingkungan di Fakultas Unair. Surabaya.

Bonnie , Ronni. (2016). Peran Polri Dalam Mengimplementasikan Restorative Justice Pada Penanganan Perkara Pidana ( Studi Di Polres Binjai). USU Law Journal.4(4),

Fahmal, Muin. (2008). Peran Asas-Asas Umum pemerintahan yang Layak Dalam Mewujudkan Pemerintahan Yang Bersih. Yogyakarta: Total Media.

M. Faal, (1991). Penyaringan Perkara Pidana Oleh Polisi (Diskresi Kepolisian), Jakarta: Pradnya Paramita Rahardjo, Satjipto. (2009). Penegakan Hukum, Suatu Tinjauan Sosiologis, Yogyakarta: Genta Publising

Susanto, F. Anton. (2004). Kepolisian dalam Upaya Penegakan Hukum di Indonesia, Jakarta: Rineka Cipta.

Thalib, Abdul Rasyid. (2006). Wewenang Mahkamah Konstitusi dan Aplikasinya dalam Sistem Ketatanegaraan Republik Indonesia. Bandung: Citra Aditya Bakti.

Act No 2 of 2002 concering the Indonesian National Police

Code of Criminal Procedure

The Regulation of Chief of the Indonesia Police Number 7 Tahun 2006

Concering the Indonesian Police's Code of ethics 